\title{
PERANCANGAN IKON WISATA BERBASIS POTENSI WILAYAH
}

\author{
Aries BM \\ Fakultas Seni Rupa dan Desain \\ Institut Seni Indonesia (ISI) Surakarta \\ ariesbm@isi-ska.ac.id
}

\begin{abstract}
The design of the tourism icon is carried out in the "Mbah Mangun" Embung in Juron Village, Subdistrict Nguter, District Sukoharjo. The method used to realize the design is through exploration, inspiration and elaboration. The exploration includes data collection in the field, documentation, literature studies and interviews. Inspiration stage is carried out in developing ideas or concept of ideas based on the analysis of data that has been obtained. The elaboration stage in this design activity represents the crystallization of ideas by strengthening the concept of the philosophy of form. This stage also considers the aspects of design realization related to the layout of icons, materials, construction and embodiment techniques.
\end{abstract}

Key words: embung, icons, tour.

\section{A. Pendahuluan}

Perancangan ini merujuk pada rencana pengembangan dan penataan wilayah melalui Musrenbang (Musyawarah, Rencana dan Pengembangan) pemerintah desa dan BPD (Badan Perwakilan Desa) tentang kelengkapan pembangunan embung Mbah Mangun di Desa Juron. Kec. Nguter, Kab. Sukoharjo. Penelitian kolaboratif, antara akademisi seni dan institusi pemerintahan tercipta melalui pembagian kegiatan sesuai dengan kapasitas masing-masing, di mana kapasitas penulis sebagai konseptor (ide, pemikiran), visualisasi desain dan prototipe, sedangkan pihak pemerintah berperan terkait pada penganggaran dan realisasi perwujudannya.

Embung Mbah mangun merupakan embung yang dibuat oleh pemerintah sejak tahun 2017, awalnya difungsikan sebagai tampungan cadangan air di musim kemarau. Lokasi embung tersebut dibuat di atas tanah seluas $5 \mathrm{Ha}$. Berdasarkan data yang penulis himpun dengan Kepala Desa setempat, bahwa lokasi embung tersebut ditargetkan mulai tahun 2020-2023 akan dibangun berbagai potensi wisata, di

antaranya adalah wisata kuliner tradisional, edukasi kuliner, museum perantauan, wisata agro dan berbagai fasilitas wisata lainnya yang memberikan nilai daya tarik bagi wisatawan. Fasilitas wisata merupakan sarana yang bertujuan untuk melayani dan mempermudah kegiatan atau aktivitas pengunjung/wisatawan yang dilakukannya untuk mendapat pengalaman rekreasi, Marpaung (2002:69).

Berdasarkan Identifikasi potensi wisata yang telah dicanangkan, selanjutnya penulis menentukan batasan objek pada perencanaan ikon wisata pada satu titik lahan yang ada, berada tepat di area pintu masuk embung. Di area tersebut direncanakan akan dibangun ikon wisata berbentuk patung keramik yang mencitrakan budaya masyarakat setempat. Sesuai perencanaan ikon patung tersebut sekaligus akan direalisasikan menjadi bangunan utama setinggi 25 meter di area tengah embung. Lahan tersebut berukuran 25 × 25 meter yang akan difungsikan sebagai fasilitas ruang kuliner dan museum perantauan. 


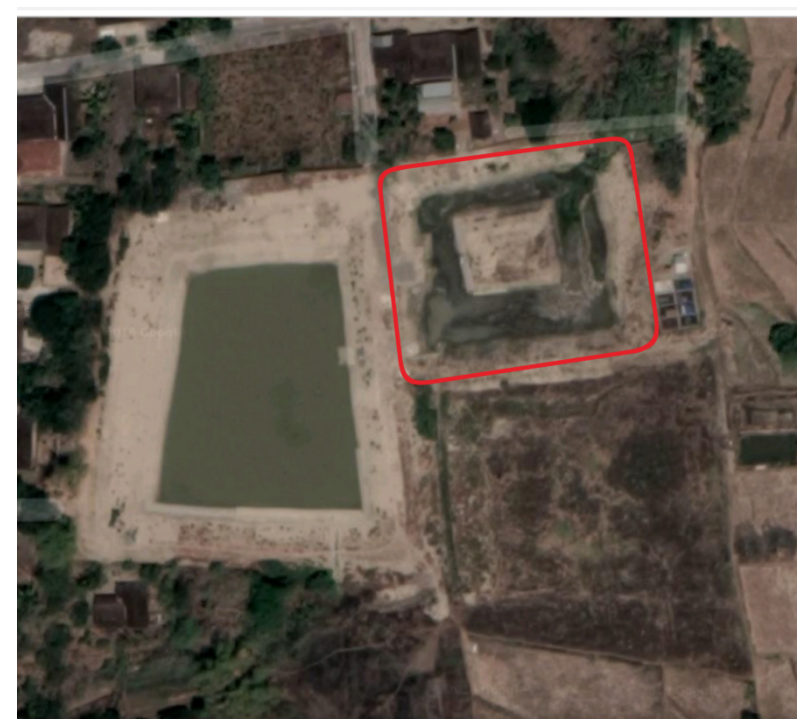

Gambar 1: Gambar tampak atas lokasi embung "Mbah Mangun" Desa Juron, dengan letak lokasi rencana pembangunan Ikon wisata dan museum perantauan ( pada bagian dengan garis merah)

(Dokumentasi Penulis)

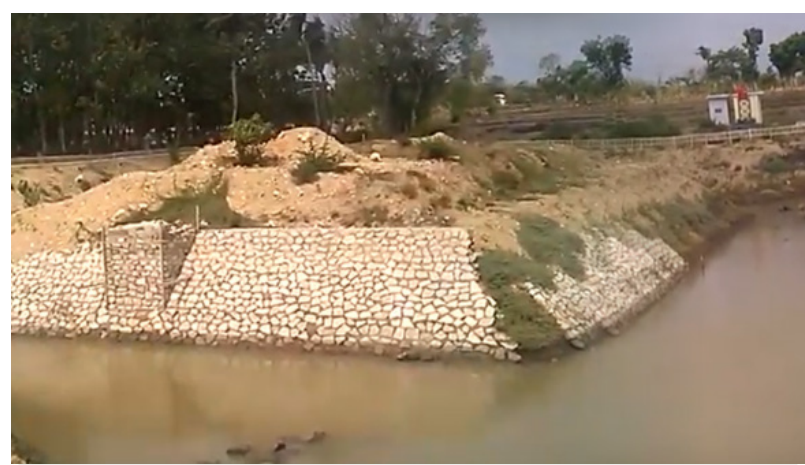

Gambar 2: Photo lokasi rencana pembangunan Ikon wisata dan museum perantauan (Dokumentasi Penulis)

Kuliner berarti masakan atau makanan. Istilah kuliner sering digunakan oleh masyarakat dalam menunjukkan makanan atau masakan suatu daerah. Pemanfaatan ruang kuliner ini direncanakan dapat bersinggungan langsung dengan kehidupan masyarakat dan melibatkan peran masyarakat Desa Juron secara aktif untuk memanfaatkan keberadaannya dalam rangka memperkenalkan dan meningkatkan eksistensi identitas lokal masyarakat Desa Juron kepada publik. Konsep ruang pusat kuliner sebagai ruang publik merupakan gagasan yang dapat diaplikasikan dalam menciptakan suatu interaksi sosial, dengan menekankan pusat kuliner sebagai fungsi utamanya.

Secara khusus rancangan ini diharapkan dapat menjadi ikon obyek wisata yang menyuguhkan artistik bentuk bangunan, keindahan alam, seni dan budaya setempat dengan menambahkan nilai-nilai sejarah, kebiasaan, tata cara hidup, cerita rakyat setempat, tradisi setempat, serta nilai-nilai keyakinan masyarakat setempat dalam konsep pariwisata pedesaan. Landasan dasar konsep pengelolaan ini mutlak diperlukan untuk menjadi desa wisata yang spesifik dan lain dari pada yang lain.

Dalam perancangan ikon wisata Desa Juron ini identitas yang ingin ditampilkan adalah potensi unggulan lokal sebagi bumi para pedagang atau perantau. Juron merupakan salah satu desa di Kabupaten Sukoharjo, secara administratif berada di wilayah Kecamatan Nguter. Jumlah penduduk desa Juron 893914 jiwa dengan rincian 449598 laki-laki dan 444316 perempuan. mayoritas penduduknya berprofesi sebagai pedagang bakso, mie ayam, es teler, ayam goreng dan jamu gendong.

Identitas inilah yang kemudian akan ditonjolkan kepada wisatawan saat berwisata di desa tersebut. Cillin (dalam Bastomi 2013: 9) beranggapan bahwa kebudayaan terdiri dari kebiasaan-kebiasaan yang terpola dan secara fungsional saling bertautan dengan individu tertentu yang membentuk grup-grup atau kategori sosial tertentu.

Melihat berbagai aspek perkembangan pariwisata tersebut, maka diperlukan sebuah studi banding untuk mengembangkan kreativitas perancangan terkait dengan ikon wisata. Hal tersebut dilakukan sebagai acuan standar atau sebagai pembanding dengan objek yang akan dirancang dalam rangka mencari peluang kebaruan dan daya saing hasil perancangan. Beberapa studi komparasi terhadap ikon wisata yang ada di antaranya adalah seperti pada gambar di bawah ini: 


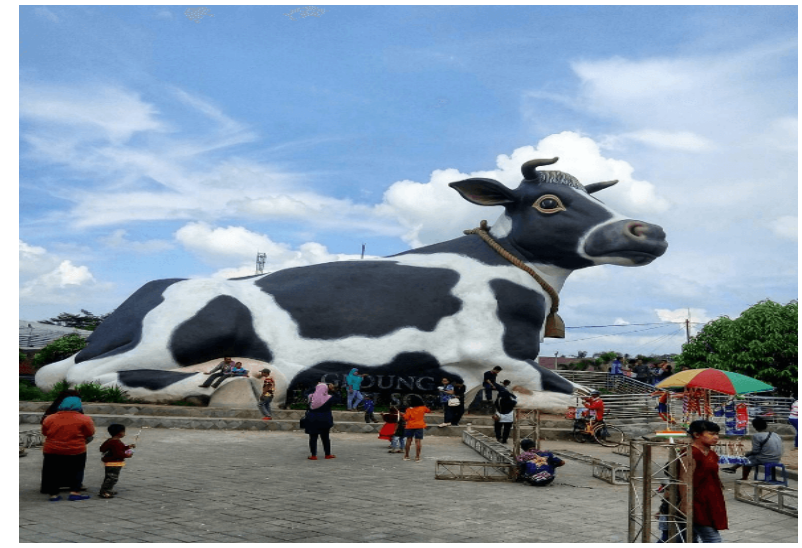

Gambar 3. Gedung Lembu Suro terletak di kota Boyolali, Jawa Tengah

Gedung Lembu Suro ini dibangun pada pertengahan November 2015. Gedung Lembo Suro atau Sapi Raksasa Boyolali ini dibangun di area tanah $18 \times 12$ meter, dengan luas bangunan $160 \mathrm{~m} 2$ dan tinggi bangunan 11 meter. Gedung Lembu Suro juga dikenal dengan nama Sapi Ndekem yang jika diartikan menjadi sapi raksasa yang sedang duduk atau mendekam. Sapi raksasa Boyolali ini seolah mempertegas bahwa kabupaten tersebut sebagai "Kota Susu" dan penghasil terbesar susu sapi di Jawa Tengah. Arsitektur bangunan patung sapi pada bagian dalam difungsikan sebagai ruang pertemuan berkonsep ala bioskop. Di tempat tersebut pemerintah setempat menghadirkan konten film singkat yang bisa ditayangkan kepada tamu penting tentang dokumentasi video pariwisata, pendidikan, infrastruktur dan potensi-potensi unggulan lainnya yang ada di Boyolali.

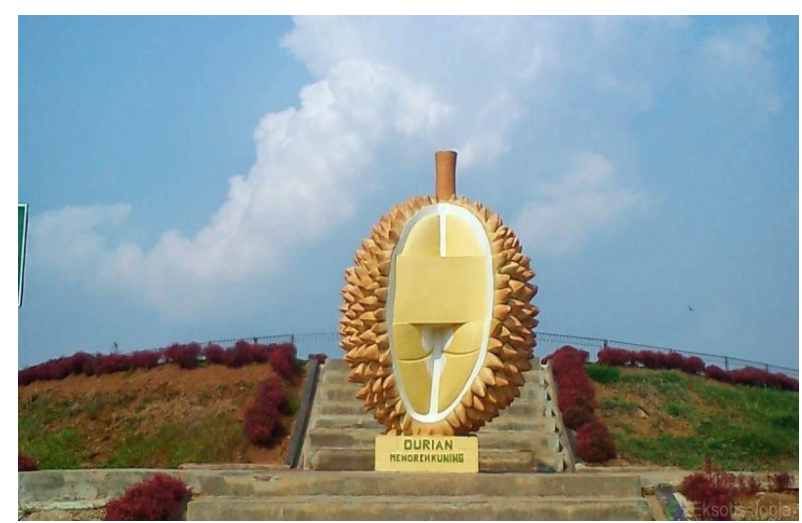

Gambar 4. Ikon berbentuk durian terletak di Embung Banjaroya Kalibawang, Kulonprogo, Yogyakarta
Patung durian berukuran relatif besar tersebut dibangun di area masuk embung Banjaroya Kalibawang, Kulonprogo, Yogyakarta yang digunakan sebagai pertanda bahwa daerah tersebut merupakan sentra penghasil durian menoreh terbaik di daerah Yogyakarta. Pembangunan embung di area tersebut didukung dengan agrowisata buah durian. Pada saat musim durian tiba sering digunakan untuk acara festival durian. Ditinjau dari aspek bentuk, patung tersebut divisualisasikan secara realis baik bentuk maupun warnanya. Sayangnya ruang sekitar patung tersebut relatif sempit, sehingga akses sirkulasi pengunjung menjadi kurang nyaman saat akan melakukan foto-foto di sekitar patung.

\section{Metode Pelaksanaan}

Secara umum proses perancangan dilakukan terdiri dari: (a) Persiapan, yakni penggalian data, observasi dan wawancara; (b) Pelaksanaan, yakni terdiri dari analisis data, perenungan, sketsa, gambar desain, dan Rencana Anggaran Biaya; (c) laporan kegiatan.

Teknik pengumpulan data yang digunakan dalam penelitian ini meliputi:

1. Wawancara dengan berbagai pihak sebagai narasumber terkait dengan embung Mbah Mangun, sejarah Desa Juron dan sejarah budaya perantauan masyarakat Desa Juron.

2. Kajian terhadap literatur yang dapat digunakan untuk mendukung dalam rancang bangun.

3. Mendokumentasikan berbagai hal melalui foto, sketsa, mengukur, dan mencatat.

Teknik analisis data dalam penelitian ini yakni mengacu pada model analisis interaktif yang meliputi tiga komponen yang meliputi reduksi data, sajian data (data display) dan pensahihan data (verifikasi). 
Secara umum tahapan yang dilalui dalam penelitian ini fokus pada kegiatan perancangan dengan mempertimbangkan aspek tata letak, material, konstruksi, teknik perwujudan dan filosofi karya secara utuh. Secara metodologis proses perancangan karya menurut Djelantik (1999: 64) menyebutkan bahwa proses penciptaan karya terdiri dari: tahapan persiapan, tahapan inkubasi, dan inspirasi, serta elaborasi. Menurut penulis, metode Djelantik di atas sangat relevan digunakan sebagai acuan dalam proses penelitian ini.

Pada tahapan persiapan awal, dilakukan pengamatan dan pencermatan terhadap lokasi embung Mbah Mangun, untuk menentukan tata letak patung keramik berikut rancangan bentuk bangunan sentra kuliner dan museum perantauan yang akan diciptakan. Dilanjutkan dengan proses observasi mendalam untuk memahami fenomena lingkungan berdasarkan pengetahuan dan gagasan yang sudah diketahui sebelumnya (untuk mendapatkan informasi yang dibutuhkan) untuk melanjutkan target penciptaan. Observasi dilakukan melalui wawancara dengan sesepuh Desa Juron untuk mencari informasi terkait dengan sejarah keberadaan embung Mbah Mangun, dan sejarah peradaban masyarakat Desa Juron terkait dengan budaya merantau sejak masa lampau.

Hasil penelusuran, yang berkaitan dengan sejumlah sejarah, fakta, problematika serta kisah-kisah yang telah terangkum, melahirkan ide awal yang kemudian dieksplorasi melalui sketsa.

Proses analisis desain terpilih didasarkan pada pertimbangan aspek fungsional, keindahan bentuk dan proses perwujudan. Analisa dari perancangan ikon wisata embung "Mbah Mangun" dilakukan mengacu pada rancangan alternatif sebagai berikut:

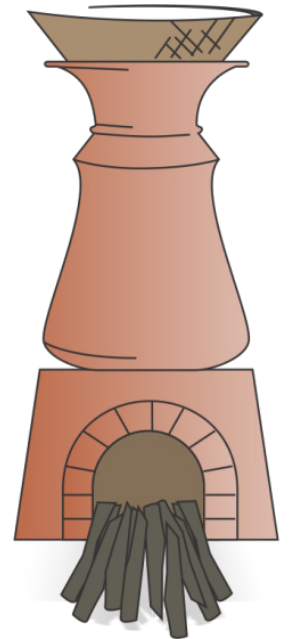

\section{Gambar 7: Rancangan alternatif 1}

Beberapa aspek yang menjadi pertimbangan pada rancangan di atas antara lain: (1) Bentuk dandang sangat responsif untuk digunakan sebagai bangunan yang memiliki ruang yang memadai untuk digunakan untuk aktivitas manusia di dalamnya. (2) Pengelompokan ruang berdasar fungsinya dapat dibuat bertingkat yang akan memberikan kemudahan komunikasi dan koordinasi bagi penggunanya. Hal ini berkaitan dengan kemudahan akses dari satu ruang ke ruang lainnya. (3) Ditinjau dari aspek pembuatan patung keramik, bentuk rancangan di atas secara struktur lebih mudah dikerjakan, karena struktur bentuknya yang tegak lurus ke atas. Bentuk silindris dandang lebih responsif dikerjakan dengan teknik putar. Tanah liat yang dibentuk dengan teknik putar relatif lebih padat dan kukuh, sehingga mengurangi resiko kegagalan pada saat pembakaran. 


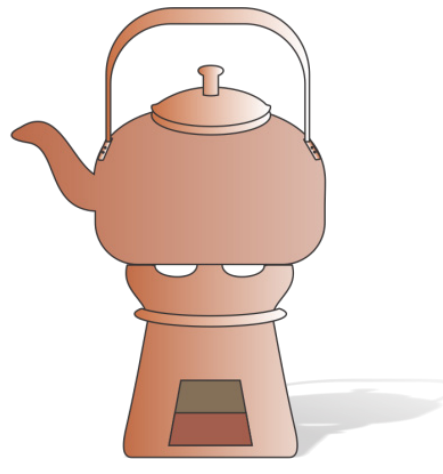

Gambar 8: Rancangan alternatif 2

Beberapa aspek yang menjadi pertimbangan pada rancangan di atas antara lain: (1) Bentuk ceret sebenarnya cukup memadai untuk digunakan sebagai bangunan untuk aktivitas manusia di dalamnya, namun pada bagian pegangan tangan dan corong air, nampaknya tidak dapat dimaksimalkan menjadi ruang, karena bentuknya yang relatif kecil dan pipih. (2) Ditinjau dari aspek pembuatan patung keramik, bentuk rancangan di atas secara struktur diperlukan dua teknik pembentukan antara lain: teknik putar untuk mengerjakan badan ceret, dan teknik pilin untuk mengerjakan bagian pegangan dan corong air. Proses pengerjaan pada bagian pegangan dan corong tersebut harus dibantu dengan penyangga untuk menopang secara bertahap menuju ke atas. Diperlukan kehati-hatian dalam proses penyambungan antar pilinan tanah liat, sehingga dimungkinkan pekerjaan tersebut cukup beresiko terhadap kegagalan pada saat pembentukan dan pembakaran.

Bentuk dan nilai-nilai simbolik pada piranti dapur atau pun alat memasak, penulis anggap mampu mewakili profesi masyarakat pedagang di Desa Juron. Keberadaaan piranti dapur ini terus mengundang perhatian penulis sebagai ruang metafora. Keberadaannya selalu memberi transformasi pengalaman setiap orang yang memiliki memori yang indah dengan hasil kenikmatan olahan makanan di dapur milik keluarga masing-masing. Menurut penulis, benda-benda tersebut sangat lekat bagi profesi pedagang.

Peralatan dapur tradisional muncul dari proses peradapan manusia dalam mempertahankan kehidupannya. Sejalan dengan perkembangan ilmu pengetahuan dan teknologi, peralatan dapur tradisional sudah mulai ditinggalkan dan digantikan oleh peralatan dapur modern. Peralatan dapur tradisional sudah ada sejak jaman nenek moyang. Manusia mulai mengenal seni kerajinan termasuk pembuatan peralatan dapur sejak mengenal tradisi bercocok tanam (Sartono, 1975: 174).

Berbagai bukti arkeologis mengenai penggunaan peralatan dapur tradisional pada masa lampau, yakni penemuan artefak (benda-benda sejarah) berupa kreweng atau pecahan gerabah. Menurut para arkeolog yang menelitinya, kreweng berasal dari pecahan peralatan untuk memasak, ada pula yang berasal dari peralatan rumah lainnya. Faktor yang menyebabkan gerabah banyak ditemukan pada situs-situs arkeologi karena sifat gerabah yang tahan dari pelapukan, sehingga mudah pecah akan tetapi tidak hancur, relatif tahan air dan tahan panas api (Ambar, 2008:1).

Permasalahan utama yang akan diungkapkan dalam penelitian ini adalah bagaimana upaya untuk melestarikan peralatan dapur tradisional melalui identifikasi jenis dan fungsinya. Selanjutnya dilakukan analisis data berdasarkan fakta dan data yang ditemukan untuk mengurai beberapa jenis dan fungsi peralatan dapur tradisional, manfaat penggunaan serta keberadaannya di dalam masyarakat saat ini.

Proses inspirasi terhadap alat dapur tersebut kemudian berkembang dengan proses perancangan berikutnya.

\section{Hasil Pembahasan}

Faktor kekuatan visual (imageability/ apparency) menjadi sangat dominan dalam penciptaan ikon wisata. Semakin kuat faktor visual, semakin kuat pula elemen tersebut diingat/dipa- 
hami oleh pengamat. Karena secara prinsip ada tiga hal dari elemen sebuah tempat akan diingat oleh pengamat, yaitu: elemen yang memberikan indentitas, elemen yang memberikan makna, elemen yang memberikan kesan estetika (baik kepada individu maupun secara sosial).

Rancangan ikon wisata ini divisualisasikan seperti halnya monumen atau pun seni patung di ruang publik. Sesuai fungsinya rancangan yang telah diciptakan akan difungsikan secara ganda. Pertama, digunakan sebagai rancangan pembangunan ruang kuliner dan museum perantauan. Kedua, rancangan serupa akan difungsikan sebagai patung keramik dalam skala relatif kecil yang menjadi ikon wisata yang dibangun di gerbang pintu masuk tempat wisata embung "Mbah Mangun".

Penelitian ini telah melakukan dua segmen rancangan di atas, namun pembahasan lebih rinci akan difokuskan pada rancangan perwujudan patung keramik sesuai dengan kompetensi yang dimiliki penulis. Rancangan yang telah penulis lakukan seperti pada gambar di bawah ini:

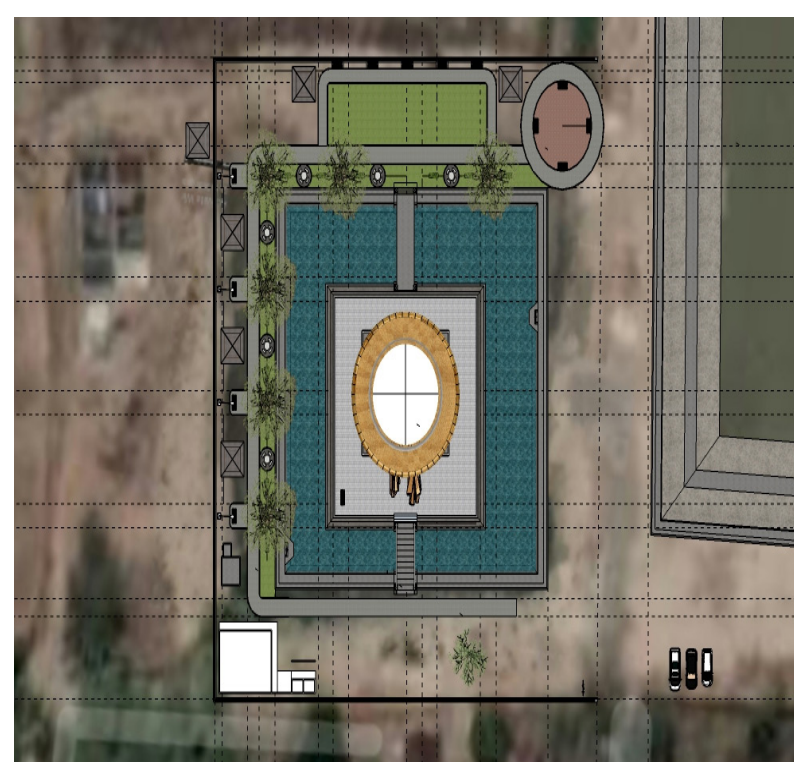

Gambar 9. Tampak atas, rancangan ikon bangunan sentra kuliner dan museum perantauan di kawasan embung "Mbah Mangun"

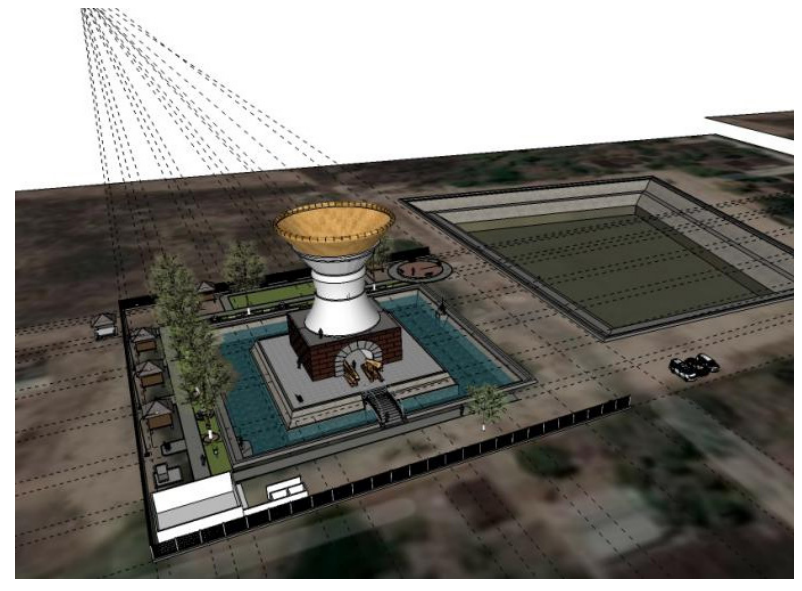

Gambar 10. Prespektif tampak atas, rancangan ikon bangunan sentra kuliner dan museum perantauan di kawasan embung "Mbah Mangun"

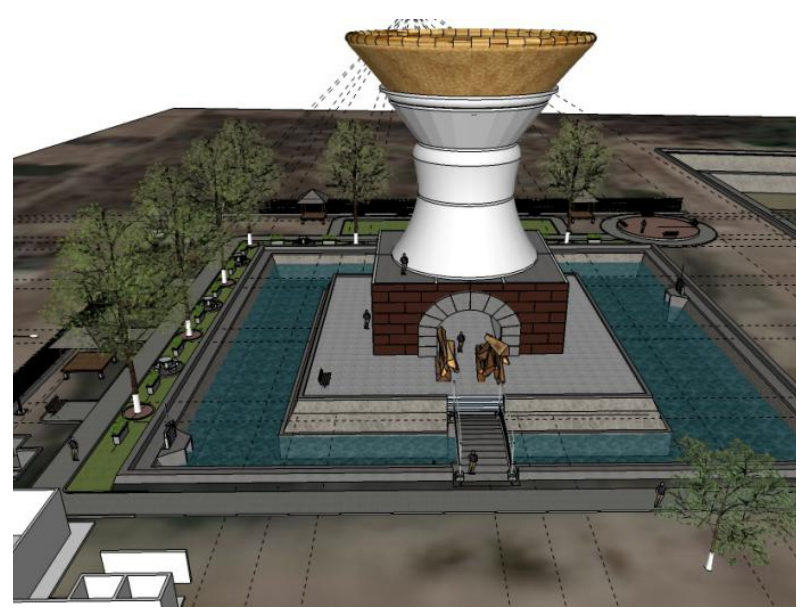

Gambar 11. Prespektif tampak depan, rancangan ikon bangunan sentra kuliner dan museum perantauan di kawasan embung "Mbah Mangun"

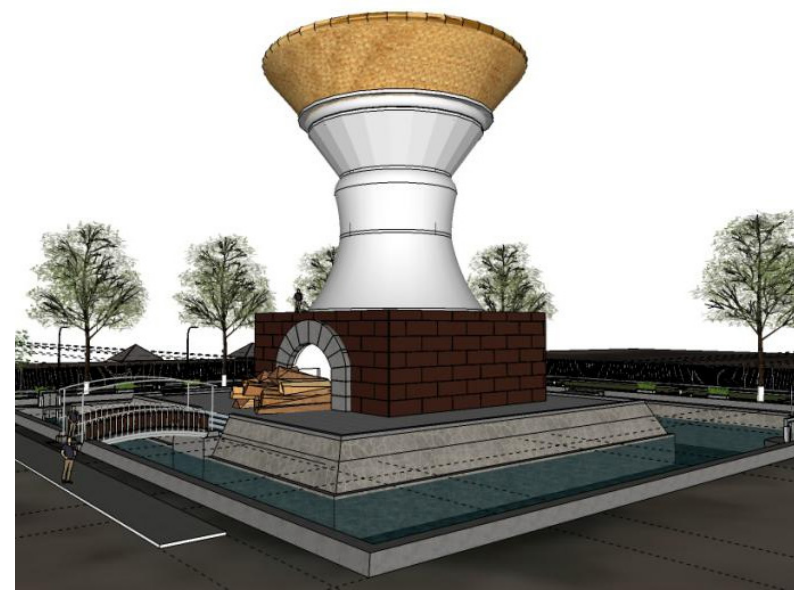

Gambar 12. Prespektif tampak kanan, rancangan ikon bangunan sentra kuliner dan museum perantauan di kawasan embung "Mbah Mangun" 


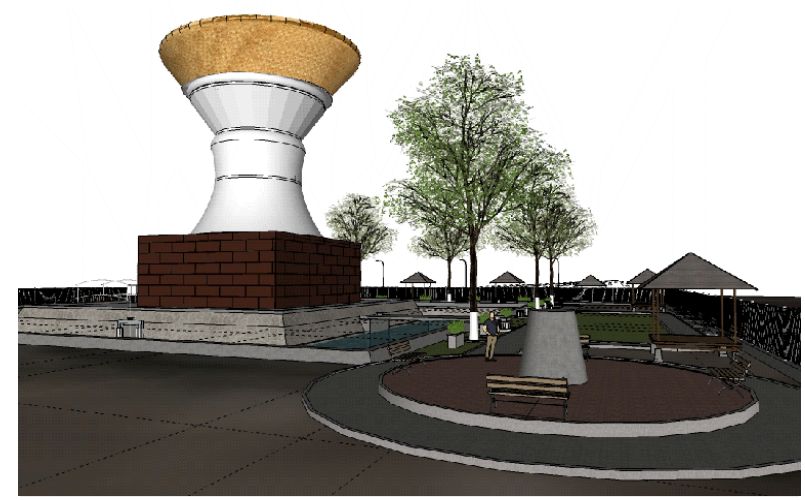

Gambar 13. Prespektif tampak belakang, rancangan ikon bangunan sentra kuliner dan museum perantauan di kawasan embung "Mbah Mangun"

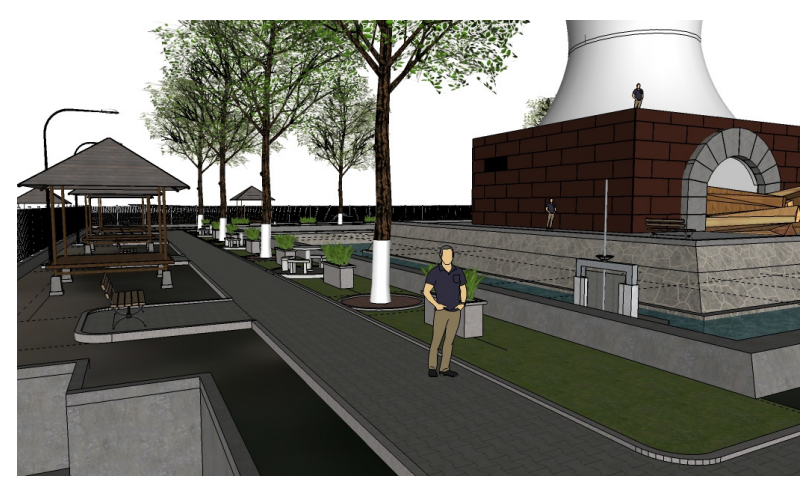

Gambar 14. Detail kawasan sekitar ikon bangunan sentra kuliner dan museum perantauan di kawasan embung "Mbah Mangun"

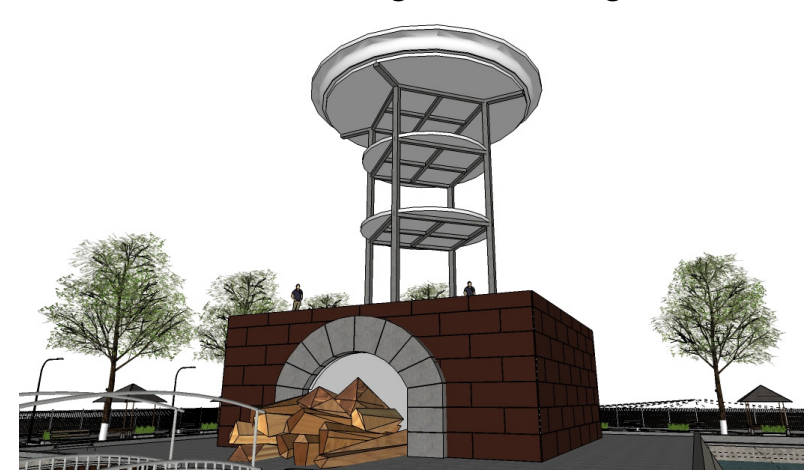

Gambar 15. Detail rancangan struktur ikon bangunan sentra kuliner dan museum perantauan di kawasan embung "Mbah Mangun"

Konsep ruang pusat kuliner dan museum perantauan sebagai ruang publik pada rancangan tersebut merupakan gagasan yang dapat diaplikasikan dalam menciptakan suatu interaksi sosial, dengan menekankan pusat kuliner sebagai fungsi utamanya.
Rancangan Lantai pertama, berfungsi untuk kios-kios masakan khas masyarakat Desa Juron. Lantai dasar ini juga berfungsi sebagai dapur untuk memamasak sajian menu kuliner yang dihadirkan untuk pengunjung. Lantai kedua, berfungsi sebagai area makan. Lantai ketiga, berfungsi sebagai museum perantauan yang mendisplay beragam piranti dapur kuno, alat-alat yang digunakan untuk berdagang kuliner kuno seperti gerobak bakso, tenggok jamu gendong dan lain-lain. Termasuk di dalamnya mendisplay beragam foto-foto kuno masyarakat perantau Desa Juron dalam aktivitas berdagang kuliner di seluruh Indonesia.

Rancangan ini diwujudkan secara kongkrit (visualized) melalui suatu upaya simbolis agar dapat tercipta dialog atau komunikasi dengan khalayak luas atau publik. Di luar fungsi fisiknya, rancangan ini memiliki kepentingan ganda, sebagai penanda sudut kawasan atau landmark, yakni sebagai sarana cermin yang merefleksikan nilai sosial budaya masyarakat Desa Juron, serta sebagai sarana pewarisan (transform) nilai tertentu yang dianggap penting, dari generasi yang satu kepada generasi lainnya (sebagai media pembangun aspek spiritualitas warganya). Sebuah ekspresi jatidiri suatu kawasan yang disebut sebagai faktor kunci dalam penciptaan rasa harga diri dan jatidiri atau identitas, dan pengejawantahan dari kesinambungan masa lampau, masa kini dan masa mendatang.

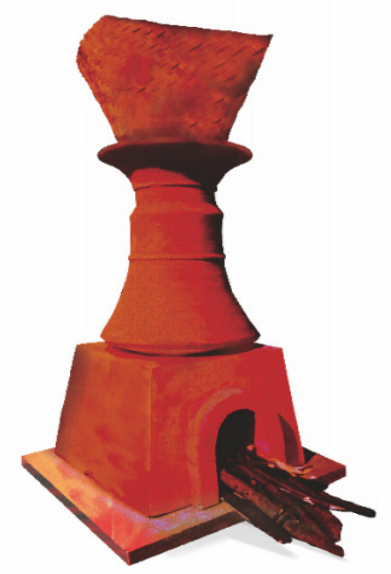

Gambar 16: Prototipe patung keramik, Ukuran 


\section{p. $23,1.20$, t. $60 \mathrm{cmMaterial}$ Keramik, kayu, bambu. Tahun 2019}

Rancangan Patung keramik di atas, diwujudkan dalam ukuran tinggi 6 meter, diletakkan di Pintu gerbang masuk kawasan Embung Mbah Mangun. Spesifikasi material dan teknik pembentukan diuraikan sebagai berikut:

Dandang, diwujudkan dengan material tanah liat stoneware menggunakan teknik pilin dan teknik putar. Pembakaran dilakukan selama 12 jam dengan suhu 1200 derajat celcius. Finishing menggunakan bahan glasir transparant 107 menutup seluruh bagian keramik berbentuk dandang. Bahan glasir akan menghasilkan warna transparant secara matt. Keramik berglasir yang diletakkan di ruang publik akan cenderung tahan terhadap cuaca dan jamur.

Tungku/Pawon diwujudkan dengan material tanah liat stoneware menjadi batu bata berukuran besar $20 \times 50 \mathrm{~cm}$, disusun secara interlocking, direkatkan dengan material semen. Pembentukan batu bata dilakukan dengan mesin cetak tekan. Pembakaran dilakukan selama 12 jam dengan suhu 1200 derajat celcius.

Kukusan diwujudkan dengan material plat kuningan yang dibentuk dengan teknik anyam.

Kayu Bakar diwujudkan dengan material kayu ulin dari Kalimantan.

Secara keseluruhan, rancangan ikon patung keramik ini secara konseptual dideskripsikan sebagai berikut :

\section{A. Dandang}

Benda bernama "dandang" merupakan peralatan dan perlengkapan dapur masa lalu yang digunakan untuk menanak nasi. Dandang oleh masyarakat pedesaan juga digunakan untuk menanak makanan seperti singkong, ketela rambat, dan umbi-umbian sejenisnya. Dandang umumnya terbuat dari bahan logam. Dandang tradisional terbuat dari tembaga, sedangkan dandang modern terbuat dari bahan aluminium. Dandang berfungsi sebagai wadah untuk mere- bus air yang uapnya digunakan untuk mengukus, sekaligus sebagai tempat diletakkannya alat lain untuk menampung beras atau nasi. Penggunaan dandang pada masa sekarang banyak digantikan oleh penanak nasi modern yang biasa disebut rice cooker.

Masyarakat Desa Juron mengenal dan mengalami berbagai mitos dandang, yakni diyakini dapat memanggil orang yang berada di tempat jauh agar cepat pulang. Caranya yakni dengan memanggil nama orang tersebut lewat lubang dandang.

Secara khusus penulis mempersepsikan makna "dandang" sebagai "dandang sendang" yang artinya membangun, memperindah dan mencitrakan kawasan embung Mbah Mangun yang semula berasal dari sumber air sendang Semurup. Sendang tersebut masih ada sampai sekarang, dan menjadi salah satu situs keramat yang akan diperindah bangunan fisiknya.

\section{B. Pawon}

Pawon merupakan bagian yang paling utama dalam dapur tradisional. Pawon dibuat secara sederhana dan diletakkan secara permanen di dalam dapur. Biasanya terbuat dari batu cadas, tanah liat ataupun dari batu bata. Terdapat lubang pembakaran di atas pawon, diameter sekitar $30 \mathrm{~cm}$, yang berfungsi untuk meletakkan alat memasak. Pawon dibuat tertutup di sekelilingnya, kecuali pada lubang tempat memasukkan kayu bakar dan bagian atas pawon, agar nyala api yang dihasilkan dapat digunakan untuk memasak.

Bentuk pawon ada dua macam, disesuaikan dengan kebutuhan pemakainya, yaitu pawon tunggal dan pawon ganda. Pawon tunggal hanya dapat digunakan untuk satu alat masak saja, sedangkan pawon ganda digunakan untuk meletakkan dua alat masak sekaligus. Pada tungku (pawon) ganda ini, lubang tempat memasukkan kayu bakar hanya satu, di bagian tengah, sedangkan bagian atas terdiri atas dua lubang yang digunakan sebagai tempat meletakkan alat memasak. Antara kedua lubang tempat 
meletakkan alat memasak tersebut tidak disekat sehingga api menyebar pada dua arah. Sebutan pawon bagi masyarakat Jawa dinamakan pula dengan dhingkel. Bentuk lain seperti dhingkel disebut pula luweng, tetapi luweng lebih panjang dan memiliki tiga sampai empat lubang. Masing-masing strukturnya memiliki nama, misal tempat untuk memasukkan kayu bakar disebut cangkem luweng. Tempat untuk meletakkan peralatan masak disebut bolongan luweng atau slowongan. Bibir dari dhingkel disebut "tumang". Sebutan batu cadas atau batu bata yang digunakan sebagai penopang pada bibir pawon bernama lawih.

Sebutan masing-masing bagian struktur pawon sangatlah unik. Hanya orang-orang Jawa kuno yang dapat menceritakan apa makna tersembunyi di balik nama yang menyertainya. Penulis menyadari penelusuran tentang hal tersebut tidaklah mudah. Diperlukan waktu dan penelitian yang berkelanjutan bagi penulis untuk mengungkap fenomena yang ada.

\section{Kayu Bakar}

Masyarakat yang masih setia menggunakan peralatan dapur tradisional dalam memasak beranggapan bahwa menggunakan bahan bakar arang dan kayu akan menimbulkan cita rasa yang berbeda apabila dibandingkan dengan makanan yang dimasak menggunakan kompor gas ataupun kompor listrik.

Memasak dengan menggunakan kayu bakar atau pun arang akan menghasilkan limbah yang berupa abu. Pada jaman dulu nenek moyang kita telah memanfaatkan limbah abu tersebut untuk berbagai keperluan. Ada yang menggunakan sebagai bahan campuran obat tradisional, sebagai pasta gigi alami dan sebagai abu gosok untuk mencuci perkakas dapur. Ramuan obat yang berasal dari abu dapur sering digunakan oleh masyarakat pada jaman dulu sebagai obat penurun demam pada anak-anak, terutama bayi. Juga dapat mempercepat proses keringnya pusar bayi yang baru lahir. Abu dapur juga digunakan sebagai pasta gigi alami yang berfungsi untuk memutihkan gigi

\section{Kukusan}

Benda berbentuk kerucut ini biasanya diletakkan ke dalam dandang dengan bagian yang lancip/ujungnya berada di bawah. Umumnya terbuat dari anyaman bambu. Kukusan ini difungsikan untuk menahan agar nasi yang ditanak pada bagian bawah tidak terkena air yang ada di dalam dandang. Uap panas yang keluar dari dandang menembus anyaman kukusan dan menimbulkan aroma yang khas.

Elemen-elemen visual yang hadir dalam kesatuan bentuk rancangan ini menggambarkan citra peralatan dapur tradisional yang diturunkan oleh nenek moyang terdahulu. Sepantasnya untuk dijaga kelestariannya sebagai warisan budaya bangsa. Perkembangan teknologi saat ini dapat mendesak unsur-unsur tradisional yang dikhawatirkan akan dapat menghilangkan tradisi ini, sehingga generasi yang akan datang tidak dapat menikmati bahkan untuk sekadar mengetahuinya saja.

Berbagai piranti dapur tradisional sejenis tungku, dandang, belanga, wajan, kendi, parutan kelapa, tempayan, irus, centong, cobek, ulekan dan lain sebagainya. mengandung nilai budaya yang menarik untuk diungkap keberadaannya.

Penelitian ini baru mengungkap sebagian dari fakta yang ada. Diperlukan sebuah pemikiran dan penelusuran yang lebih luas untuk menghimpun seluruh piranti tradisional ini. Tentu juga diperlukan waktu dan perhatian yang memadai untuk hal tersebut. Penulis berharap dapat melakukannya pada proyek penelitian berikutnya. 


\section{Kesimpulan}

Merumumuskan konsep optimalisasi peran ikon patung dalam membentuk identitas pada konteks perancangan branding wisata, harus mempertimbangkan secara matang hal-hal sebagai berikut:

- a. Kondisi eksisting lokasi pembangunan dan masyarakatnya dalam sebuah wilayah, agar tercipta sebuah perancangan yang mampu merangkum secara utuh citra yang dibangun.

- b. Diperlukan observasi mendalam untuk mewujudkan konsep perancangan ikon wisata. Hal tersebut dilakukan melalui pengumpulan data dari Informan/ narasumber terkait tentang seluruh potensi wilayah yang ada berkaitan dengan kondisi alam, nilai-nilai sejarah, kebiasaan, tata cara hidup, cerita rakyat, tradisi setempat, nilai-nilai keyakinan masyarakat setempat dan lain-lain.

- c. Diperlukan studi banding untuk mengembangkan kreativitas perancangan terkait dengan ikon wisata. Hal tersebut dilakukan sebagai acuan standar atau sebagai pembanding dengan objek yang akan dirancang dalam rangka mencari peluang kebaruan dan daya saing hasil perancangan.

- d. Diperlukan literatur, baik berupa buku, jurnal, mass media, maupun sumber tertulis lainnya yang mendukung teori perancangan.

\section{Saran}

Optimalisasi penempatan ikon patung sebagai citra wilayah sebaiknya diletakkan pada titik-titik terbaik, agar view ikon tersebut dapat terlihat secara maksimal. Hal tersebut perlu mempertimbangkan analisis pengguna dan aktivitasnya agar sesuai dengan fungsi yang diperlukan.

\section{Daftar Pustaka}

Ashihara, Yoshinobu. 1986. Perancangan Eksterior dalam Arsitektur. Abdi Widya. Bandung

Ahimsa-Putra, Shri Hedy, A. Sujito, dan W. Trisnadi. 2001. "Pengembangan Model Wisata Pedesaan sebagai Alternatif Pembangunan Berkelajutan." Laporan Penelitian Hibah Bersaing. Yogyakarta: LPPM UGM.

Alexander Brian, 2001. Kamus Keramik. Jakarta. Milenia Populer.

Astuti Ambar, 1997. Pengetahuan Keramik. Yogyakarta. Gadjah Mada University Press.

Dermawan, T. Agus, 2001, “Tanda-tanda Tempat Bernama Landmark".Katalog Gelar Karya Sayembara Landmark Ancol.Jakarta : P.T. Pembangunan Jaya Ancol

Dharsono, 2007. Estetika. Bandung. Rekayasa Sains.

Damanik, Janianton. 2013. Pariwisata Indonesai: Antara Peluang dan Tantangan. 1 ed. Yogyakarta: Pustaka Pelajar.

Putra Ahimsa, S.H.. Seni Kriya dan Pelestariannya Di Indonesia. Yogyakarta. Makalah disampaikan dalam seminar nasional kriya di ISI Yogyakarta 5 Mei 2009.

Razak, R.A. 1993. Industri keramik. Jakarta. Balai Pustaka.

Soedarso, SP. 1991. Beberapa Catatan Tentang Perkembangan Kesenian Kita . Yogyakarta. Penerbit BP ISI Yogyakarta.

Sachari Agus, 2007. Budaya Visual Indonesia. Jakarta. Erlangga.

Tabrani Primadi, 2005. Bahasa Rupa. Bandung. Kelir.

Zahn, Markus, 1999, Perancangan Kota Secara Terpadu : Teori Perancangan Kota dan Penerapannya, Yogyakarta, Kanisius 